\title{
Análise da variante Arg128Cys no gene DPT em indivíduos com hipótese diagnóstica de doença de Ménière.
}

\author{
Beatriz M. S. Pereira*, Geovana A. Carneiro*, Júlia S. Andreoti ${ }^{\star}$, Giselle B. Bortoletto, Matheus T. Galeni, Nadya \\ S. M. Adamov, Edi L. Sartorato.
}

\section{Resumo}

A Doença de Ménière (DM) é uma labirintopatia caracterizada pela tétrade sintomática: vertigem, perda de audição, zumbido e plenitude aural. É mais frequente em adultos caucasianos entre 30 e 50 anos. Sua etiologia permanece desconhecida, mas sabe-se que fatores genéticos e ambientais estão envolvidos. Uma variante rara no gene DPT codificante da proteína dermatopontina - foi recentemente associada a essa condição. Portanto, o objetivo deste projeto foi rastrear a alteração p.Arg182Cys no gene DPT em 10 pacientes com DM, atravez do método de Sequenciamento Automático de Sanger. Não foi encontrada a variante em nenhum dos 10 indivíduos.

Palavras-chave: Doença de Ménière, Perda Auditiva, DPT.

\section{Introdução}

A doença de Ménière (DM) é uma condição crônica multifatorial associada ao acúmulo da endolinfa no ouvido interno (uma hidropisia endolinfática idiopática) caracterizada pela tétrade sintomática de vertigem, perda de audição, plenitude aural e zumbido. (Gibson, 2010)

A manifestação ocorre entre os 30 e 50 anos, sendo unilateral e podendo evoluir para casos bilaterais, mais comuns quando há histórico familiar, sendo esse mais precoce e severo. No entanto, casos esporádicos são a maioria. Padrões de herança autossômica dominante e recessiva já foram descritos. (Ganança et al. 2002, Arweiler et al. 1995, Morrison \& Johnson, 2002)

Sua causa ainda é desconhecida, mas considera-se que provém de fatores primariamente genéticos, representando 50 a $60 \%$ dos casos. O gene DPT codificante da proteína dermatopontina - que ajuda a manter a homeostase vascular, vem sendo relacionado à DM. A variante Arg182Cys no Exon 4 já foi reportada em heterozigose segregando juntamente com o fenótipo da DM em estudos feitos por Martín-Sierra. (Vrabec et al. 2010; Martín-Sierra et al. 2017)

Diante disto, esse projeto teve como objetivo o rastreamento da variante Arg182Cys em 10 pacientes diagnosticados clinicamente com a Doença de Ménière.

\section{Resultados e Discussão}

A análise da variante Arg128Cys foi feita por meio do Sequenciamento Automático de Sanger, porém não foi encontrada em nenhum dos 10 pacientes estudados neste projeto. No entanto, foram encontradas outras variantes recorrentes: rs78760104 (c. ${ }^{*} 39$ * 40 insA) em nove pacientes, rs12060879 (c.582C>T) em três pacientes, e em apenas um paciente foi encontrada a variante rs114910915 (c. ${ }^{*} 61 T>C$ ). Contudo, estas são variantes polimorficas não relacionadas à Doença de Ménière.
A alteração Arg128Cys está localizada no Exon 4 do gene DPT, e representa uma mudança estrutural relevante nas propriedades da proteína. Porém, ainda não se sabe determinar se ela causa interações com outros sítios de ligação.

O estudo de Martín-Sierra et al. (2017) classificou a alteração Arg128Cys missense no gene DPT como rara, estando presente em somente $0,00025 \%$ da população. Este estudo reportou 0 alelo $T$ em três mulheres da mesma família na mesma geração, e em duas pessoas com SNHL (Perda Auditiva Neurosensorial). Martín-Sierra ainda afirma que foi encontrada esta mesma alteração em outros três indivíduos de populações Latina, Sul-Asiática e Européia. (Matín-Sierra et al. 2017)

\section{Conclusões}

A variante Arg182Cys não foi encontrada em nenhum dos pacientes analisados nesse projeto.

No entanto, não se pode afirmar que não tenha relação com a Doença de Ménière, fazendo-se necessário estudos mais avançados a respeito do assunto.

\section{Agradecimentos}

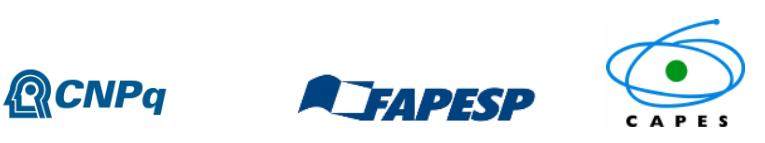

\section{LBMंË $\dot{\boldsymbol{C}}$}

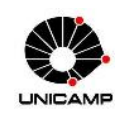

Carmen Martin-Sierra, Alvaro Gallego-Martinez, Teresa Requena, Lidia Frejo, Angel Batuecas-Caletrío and Jose A Lopez-Escamez. Variable expressivitty and genetic heterogeneity involving DPT and SEMA3D genes in autossomal dominant familial Meniere's disease. European Journal of Human Genetics (2017) 25, 200-207.

Morrison A.W. \& Johnson K.J. Genetics (molecular biology) and Ménière's disease. Otolarygol Clin North Am, 2002; 35(3), 497 - 516.

Vrabec J.T. Genetic investigation of Ménière's disease. Otolarygol Clin North Am, 2010; 43(5), $1121-1132$

Arwelier D.J., Jahnke K. \& Grosse-Wilde H. Ménière disease as autosome dominant hereditary disease, Laryngorhinootologie, 1995; 78(8), 512-515.

Karen de Carvalho Lopes. Estudo molecular na Doença de Ménière: genes AQP2, AQP3, KCNE1, GJB2 e GJB6 [tese]. São Paulo: Universidade Federal de São Paulo (UNIFESP); 2015. 